\title{
Long-Term Water Balance in a Semiarid Shrubland
}

\author{
Bradford P. Wilcox, ${ }^{1}$ Steven L. Dowhower, ${ }^{2}$ W. Richard Teague, ${ }^{3}$ \\ and Thomas L. Thurow ${ }^{4}$ \\ Authors are ${ }^{1}$ Professor, Department of Rangeland Ecology and Management, Texas A\& M University, College Station, TX 77843; \\ ${ }^{2}$ Senior Research Associate, Texas Agricultural Experiment Station, Vernon, TX 76385; ${ }^{3}$ Professor, Texas Agricultural \\ Experiment Station, Vernon, TX 76385; and ${ }^{4}$ Professor, Department of Renewable Resources, \\ University of Wyoming, Laramie, WY 82071.
}

\begin{abstract}
Baseline information on the water balance is essential for adequately understanding ecohydrological relationships on rangelands. Unfortunately, such information is not always available, because insufficient data have been collected and/or the data do not represent relevant temporal or spatial scales. In particular, for many rangelands long-term records of runoff at the small catchment or larger scales are relatively rare. In this study, we used catchment-scale data, collected over nearly a decade, to estimate the long-term water balance for mesquite-juniper rangelands in the Rolling Plains of Texas. The data include precipitation, surface runoff, soil water, and vegetation cover; these were measured on 9 microcatchments, each about 1.4 ha in size. Soil water was determined by neutron-probe measurements to a depth of $120 \mathrm{~cm}$. Surface runoff was, surprisingly, a very small component $(<1 \%)$ of the water budget and occurred only during extraordinary precipitation events. Soil-water recharge resulted mainly from winter precipitation. Evapotranspiration, which took place during the entire year, ranged from less than $1 \mathrm{~mm} \cdot \mathrm{day}^{-1}$ during the winter to almost $8 \mathrm{~mm} \cdot \mathrm{day}^{-1}$ during the summer. This study is important because it clearly documents how water is allocated on these rangelands at spatial and temporal scales that are relevant to management. The results from this study, in conjunction with other work in the Rolling Plains, suggests that there is little potential for increasing water yield via brush control in these landscapes.
\end{abstract}

\section{Resumen}

La información base sobre el balance de agua es esencial para entender adecuadamente las relaciones ecohidrológicas de los pastizales. Desafortunadamente, tal información no siempre esta disponible debido a que los datos colectados son insuficientes y/o no representan las escalas temporales/espaciales relevantes. En particular, para muchos pastizales, los registros a largo plazo de escurrimiento en pequeñas áreas de captación o en escalas grandes son relativamente raros. En este estudio usamos los datos a escala de área pequeñas de captación, colectados por casi una década para estimar el balance de agua a largo plazo para los pastizales de "Mesquite/Juniper" en las planicies onduladas de Texas. Los datos incluyen precipitación, escurrimiento superficial, y cobertura de la vegetación que fueron medidas en nueve micro estructuras de captación, cada una de 1.4 ha de tamaño. El agua del suelo fue determinada con mediciones de una sonda de nutrones a una profundidad de $120 \mathrm{~cm}$. El escurrimiento superficial fue, sorprendentemente, un componente pequeño $(<1 \%)$ del balance de agua y ocurrió solo durante eventos extraordinarios de precipitación. La recarga de agua del suelo resultó principalmente de la precipitación invernal. La evapotranspiración, que se dio todo el año, varió de menos de $1 \mathrm{~mm} \cdot$ día $^{-1}$ durante el invierno a casi $8 \mathrm{~mm} \cdot$ día $^{-1}$ durante el verano. Este estudio es importante porque documenta claramente como el agua es distribuida en estos pastizales a escalas temporal y espacial que son relevantes para el manejo. Los resultados de este estudio, en conjunto con otro trabajo en las planicies onduladas, sugieren que hay poco potencial para incrementar el rendimiento de agua vía el control de arbustos en esos paisajes.

Key Words: range hydrology, mesquite, redberry juniper, runoff, evapotranspiration, soil water

\section{INTRODUCTION}

Worldwide, vast areas of rangeland have converted from grasslands or savannas to woodlands-a phenomenon often described as woody plant encroachment (Archer 1989, 1996). In Texas and other parts of the southwestern United States, 2 woody plant species that have increased in density and extent are honey mesquite (Prosopis glandulosa Torr.) and redberry

This research was partially funded by the Texas Agriculture Experiment Station.

Correspondence: Bradford P. Wilcox, Dept of Rangeland Ecology and Management, Texas A\&M University, College Station, TX 77843. Email: bwilcox@tamu.edu

Manuscript received 26 January 2006; manuscript accepted 18 August 2006. juniper (Juniperus pinchotii Sudw.). In Texas alone, mesquite woodlands cover an estimated 22 million hectares (Scifres 1980), and redberry juniper woodlands cover another 5 million hectares (Ansley et al. 1995). In some cases, the 2 types actually commingle (Ansley et al. 1995, 2001; Asner et al. 2003). The conversion of grasslands to woodlands has obvious and farreaching implications, from a socioeconomic (Thurow et al. 2001) as well as an ecological perspective (Scholes and Archer 1997). In addition, concern is growing that dramatic increases in woody plant cover may profoundly affect biogeochemical cycles (Archer et al. 2001) and the water cycle (Huxman et al. 2005).

To understand these cycles and how they are affected by changes in woody plant cover, one must first develop a sound 


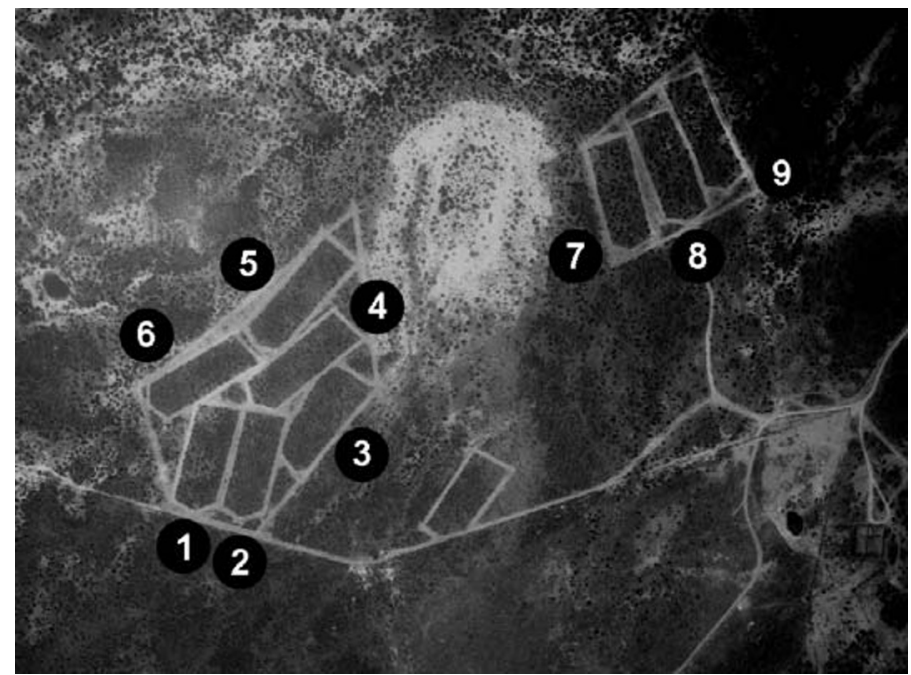

Figure 1. The boundaries of the microcatchments, each of which measures $80 \times 180 \mathrm{~m}$, are outlined in an aerial photograph taken in July 1993.

knowledge of how climate, water, and vegetation dynamics interact. Although some data on these interactions are available for smaller scales (Loik et al. 2004; Ogle and Reynolds 2004; Reynolds et al. 2004; Schwinning et al. 2004), they are relatively rare at the catchment or larger scales for most semiarid systems.

With respect to the specific question of whether decreasing woody plant cover will lead to increases in streamflow and/or recharge, a better understanding of water balance relationships in these shrublands is needed. Although increased water yield is commonly cited as justification for woody-plant-reduction programs, it is uncertain to what extent such increases are achievable-largely because of the lack of baseline information on the water balance over multiple years (Newman et al. 2006; Wilcox and Thurow 2006). This lack is especially acute for mesquite and redberry juniper rangelands (Wilcox 2002; Wilcox et al. 2006).

The study reported on here is not a manipulative experiment, but rather a long-term evaluation of the water budget of a mesquite rangeland in the Rolling Plains of Texas that is undergoing secondary invasion by redberry juniper. In particular, we are interested in the magnitude and frequency of surface runoff in landscapes of this type, with deep soils; we hypothesize that it is relatively infrequent and of small magnitude.

\section{STUDY SITE}

The study site is located on the Y Experimental Ranch, located $25 \mathrm{~km}$ southwest of Crowell (lat $33^{\circ} 52^{\prime} \mathrm{N}$, long $100^{\circ} 00^{\prime} \mathrm{W}$ ) in north-central Texas. The site consists of 9 microcatchments, each about $80 \mathrm{~m}$ wide by $180 \mathrm{~m}$ long, or 1.4 ha (Fig. 1). The pasture in which all the microcatchments are located was moderately stocked, at approximately 0.06 animal unit years (AUY) ha ${ }^{-1}$ (16 ha AUY ${ }^{-1}$ ), for the duration of the study.

The climate, characterized by hot summers and relatively dry winters, is classified as subtropical subhumid (Larkin and
Bomar 1983). Annual precipitation at Crowell averages 617 mm (Teague et al. 2001). The average annual potential evapotranspiration, at some $1900 \mathrm{~mm} \cdot$ year $^{-1}$ (Larkin and Bomar 1983), is about 3 times greater than the average annual precipitation.

Honey mesquite and redberry juniper are the dominant shrubs. Dominant herbaceous species include tobosagrass (Hilaria mutica [Buckl.] Benth.), sideoats grama (Bouteloua curtipendula [Michx.] Torr.), Texas wintergrass (Nassella leucotricha [Trin. \& Rupr.] Pohl), buffalograss (Buchloe dactyloides [Nutt.] Engelm.), annual broomweed (Gutierrezia texanum [DC.] Torr. \& A. Gray), and western ragweed (Ambrosia psilostachya DC.) (Teague et al. 2001).

Soils at the site are classified as Tilman clay loam (fine, mixed, thermic Typic Paleustoll). These soils are formed in the residuum, predominantly clay and shale, of Permian redbed materials; they are relatively deep (up to $2 \mathrm{~m}$ ), are welldeveloped, and are thought to have low permeability because of their high clay content (Koos et al. 1962).

\section{METHODS AND MATERIALS}

Our analysis is based on multiple-year vegetation and hydrologic data (collected over a 9-year period) from the 9 microcatchments.

\section{Vegetation Data}

Sampling of vegetation was carried out from 1992 to 2002, during most spring, summer, and fall periods. Within each microcatchment, herbaceous and woody plant cover was estimated at $15-\mathrm{m}$ intervals along randomly located $60-\mathrm{m}$ transect lines (5 sampling locations per transect). From 1992 to 1997 , we sampled along 8 transect lines (40 locations) in each microcatchment; then from 1997 to 2002, we scaled back to 4 transects per microcatchment. Herbaceous composition was determined on the basis of data from $200.05-\mathrm{m}^{2}$ plots $(0.2 \times 0.25 \mathrm{~m})$ per microcatchment, as described by Dowhower et al. (2001). Bare ground, litter, and herbaceous aerial cover were estimated visually for each plot to bring the total to $100 \%$. In 4 quadrants of a $360^{\circ}$ radius around each sampling point, woody plant aerial cover and woody plant abundance were also estimated. If the height of woody plants in a given quadrant was less than $45^{\circ}$ vertically from the sampling point, the brush was considered to be of minimal abundance and was assigned a score of 0 ; if the brush partially filled the quadrant $\left(45^{\circ}\right.$ to $\left.74^{\circ}\right)$, a score of 1 was assigned; and if the quadrant was filled with brush $\left(75^{\circ}\right.$ to $\left.90^{\circ}\right)$, a score of 2 was assigned. Summing of the values for all 4 quadrants yielded a score of between 0 and 8 , with each increment representing approximately $12.5 \%$ of the cover (a score of 8 , thus, would mean $100 \%$ woody plant cover). This technique for estimating woody plant cover compares very favorably $\left(R^{2}=0.96\right)$ with the standard line-intercept method (Dowhower, unpublished data, 1998-2000).

\section{Hydrologic Data}

The water balance of a region is an expression of how precipitation is apportioned after it arrives on the land surface 
Table 1. Woody plant and herbaceous aerial cover for each microcatchment averaged over the study period.

\begin{tabular}{|c|c|c|c|c|c|c|c|c|c|c|}
\hline \multirow[b]{2}{*}{ Cover category } & \multicolumn{9}{|c|}{ Microcatchment } & \multirow{2}{*}{$\begin{array}{c}\text { Tukey minimum } \\
\text { significant difference } P<0.05\end{array}$} \\
\hline & MC1 & MC2 & MC3 & MC4 & MC5 & MC6 & MC7 & MC8 & MC9 & \\
\hline & \multicolumn{9}{|c|}{ Slope $(\%)$} & \\
\hline & 2 & 1.9 & 2.1 & 2.1 & 2.2 & 1.6 & 2.4 & 1.7 & 1.8 & \\
\hline \multicolumn{11}{|l|}{ Woody plant aerial cover (\%) } \\
\hline Prosopis glandulosa Torr. & 34 & 46 & 43 & 42 & 41 & 37 & 16 & 16 & 17 & 6.4 \\
\hline Juniperus pinchoti Sudw. & 12 & 6 & 5 & 11 & 8 & 16 & 34 & 29 & 28 & 6.0 \\
\hline Opuntia sp & 9 & 7 & 6 & 7 & 8 & 6 & 7 & 9 & 6 & 2.7 \\
\hline Other shrubs & 2 & 1 & 0 & 1 & 2 & 3 & 2 & 3 & 5 & 1.5 \\
\hline \multicolumn{11}{|l|}{ Herbaceous aerial cover (\%) } \\
\hline Grass & 35 & 43 & 46 & 42 & 44 & 36 & 33 & 32 & 34 & 5.8 \\
\hline Forbs & 7 & 6 & 5 & 5 & 5 & 6 & 7 & 7 & 7 & 2.8 \\
\hline Litter & 40 & 42 & 42 & 44 & 43 & 45 & 42 & 41 & 38 & 7.1 \\
\hline Bare & 17 & 9 & 7 & 9 & 7 & 12 & 18 & 20 & 21 & 4.0 \\
\hline
\end{tabular}

(Wilcox et al. 2003). A simplified representation of the water balance is as follows:

$$
P=E T+R+G+\Delta S,
$$

where $\mathrm{P}=$ precipitation, $\mathrm{ET}=$ evapotranspiration, $\mathrm{R}=$ runoff, $\mathrm{G}=$ groundwater recharge or deep drainage, and $\Delta S=$ change in soil water.

In this study, we measured $\mathrm{P}, \mathrm{R}$, and $\Delta \mathrm{S}$ directly; ET was estimated as the difference between measured input $(\mathrm{P})$ and measured output ( $\mathrm{R}$ plus $\Delta \mathrm{S}$ ); and $\mathrm{G}$ was assumed to be 0 on the basis of previous $G$ estimates from mesquite rangelands having similar climate, soil, and vegetation (Carlson et al. 1990). This methodology does have drawbacks, in that 2 of the water-budget components are not measured directly, and the accuracy of the results depends on the validity of our assumption that recharge is 0 . In reality, periods of exceptional precipitation during the cool season may result in small amounts of water percolating deep into the soil. For example, a 3-year water-budget calculation for a similar study site on the Texas Rolling Plains documented that $0.4 \%$ of precipitation percolated beyond the depth of $3 \mathrm{~m}$ (Carlson et al. 1990). Scanlon et al. (2005) and Seyfried et al. (2005) concluded that semiarid rangelands with deep silt or clay soils have negligible potential for deep drainage.

Surface runoff was monitored from each of the 9 1.4-ha microcatchments. We felt that catchments of this size were large enough to capture important processes at the landscape scale. The microcatchment perimeters were delineated by $0.3-\mathrm{m}$-high soil berms pushed up with a bulldozer. For monitoring of surface runoff, each microcatchment was instrumented with $0.9-\mathrm{m} \mathrm{H}$ flumes and FW-1 stage recorders. Precipitation was measured by a mechanical weighing rain gauge with a chart recorder (backed up by 2 manual gauges that were monitored for the duration of the study). Runoff and precipitation data were collected for 9.5 years-from June 1993 through December 2002. Beginning in September 1998, the precipitation data were supplemented by readings from a tipping-bucket rain gauge.

A neutron probe was used to measure volumetric soil water content within each microcatchment, at 3 (in one case, 4) locations-28 locations in all. Access tubes were installed to a depth of around $120 \mathrm{~cm}$, and soil water was measured biweekly or monthly from April 1994 to December 1999 at depths of $15,30,60,90$, and $120 \mathrm{~cm}$. To calculate total soil water storage, we assumed that the water content measured at each depth was representative of that above and below the measurement depth-i.e., that average soil water at $15 \mathrm{~cm}$ was representative of the 0 - to $22.5-\mathrm{cm}$ depth interval; soil water at $30 \mathrm{~cm}$ was representative of the 22.5 - to $45-\mathrm{cm}$ depth interval; soil water at $60 \mathrm{~cm}$ was representative of the 45 - to $75-\mathrm{cm}$ depth interval; soil water at $90 \mathrm{~cm}$ was representative of the 75 - to $105-\mathrm{cm}$ depth interval; and soil water at $120 \mathrm{~cm}$ was representative of the 105 - to $135-\mathrm{cm}$ depth interval.

For each sampling date, depth, and location, we computed a "relative soil water content" by subtracting the minimum storage value recorded at that particular depth and location. Average soil storage for each date and depth was calculated by averaging the relative water contents across all 28 locations.

Using a simple water balance approach, we were able to estimate the amount of ET that occurred between the dates that soil water was measured-that is, ET $=P-R-\Delta S$, expressed in $\mathrm{mm} \cdot \mathrm{day}^{-1}$. As mentioned above, deep drainage was assumed to be 0 . This assumption is well supported by other studies in mesquite rangelands (Carlson et al. 1990; Weltz and Blackburn 1995) as well as by findings for other semiarid shrublands (Scanlon et al. 2005; Seyfried et al. 2005).

\section{RESULTS}

\section{Vegetation}

Shrub cover on all the microcatchments is a mix of mesquite and juniper. The 6 microcatchments in the eastern portion of the study site (MC1-MC6) are dominated by mesquite, whereas the 3 microcatchments in the western portion (MC7-MC9) have more redberry juniper (Fig. 1; Table 1). The western catchments generally have lower grass cover and more bare ground as well (Table 1). During the decade of observation, the coverage of mesquite and juniper averaged 
Table 2. Precipitation and runoff from each microcatchment by year.

\begin{tabular}{|c|c|c|c|c|c|c|c|c|c|c|c|}
\hline \multirow[b]{2}{*}{ Year } & \multirow{2}{*}{$\begin{array}{l}\text { Precipitation } \\
\qquad(\mathrm{mm})\end{array}$} & \multicolumn{10}{|c|}{ Microcatchment } \\
\hline & & MC1 & MC2 & MC3 & MC4 & MC5 & MC6 & MC7 & MC8 & MC9 & AVG \\
\hline & & \multicolumn{10}{|c|}{ Runoff (mm) } \\
\hline $1993^{1}$ & 330 & 0.0 & 0.3 & 0.0 & 0.1 & 0.3 & 0.0 & 1.0 & 1.1 & 1.4 & 0.5 \\
\hline 1994 & 512 & 0.0 & 0.0 & 0.0 & 0.1 & 0.1 & 0.0 & 0.0 & 2.2 & 0.2 & 0.3 \\
\hline 1995 & 912 & 3.0 & 40.8 & 47.4 & 6.3 & 35.0 & 19.6 & 4.2 & 5.1 & 5.0 & 18.5 \\
\hline 1996 & 337 & 0.0 & 0.0 & 0.0 & 0.0 & 0.0 & 0.0 & 0.0 & 0.2 & 0.0 & 0.0 \\
\hline 1997 & 941 & 0.0 & 13.2 & 11.1 & 0.0 & 6.0 & 3.8 & 0.2 & 2.3 & 0.0 & 4.1 \\
\hline 1998 & 373 & 0.0 & 1.8 & 1.8 & 0.0 & 0.2 & 0.9 & 0.0 & 0.3 & 0.0 & 0.5 \\
\hline 1999 & 776 & 0.0 & 4.1 & 3.8 & 0.5 & 3.5 & 5.2 & 0.3 & 3.9 & 0.3 & 2.4 \\
\hline 2000 & 650 & 0.1 & 4.3 & 2.5 & 0.2 & 7.8 & 4.8 & 0.7 & 2.3 & 0.3 & 2.6 \\
\hline 2001 & 449 & 0.0 & 0.0 & 0.0 & 0.0 & 0.0 & 0.0 & 0.0 & 0.4 & 0.0 & 0.0 \\
\hline 2002 & 826 & 0.0 & 0.0 & 0.0 & 0.0 & 1.5 & 0.0 & 0.0 & 0.0 & 0.0 & 0.2 \\
\hline Total & 6106 & 3.1 & 64.4 & 66.6 & 7.2 & 54.4 & 34.3 & 6.3 & 17.8 & 7.1 & 29.0 \\
\hline
\end{tabular}

${ }^{1}$ Data collected from June through December.

across all the microcatchments increased from $45 \%$ to $52 \%$ $(P=0.104)$. Herbaceous and litter cover fluctuated with climate and intensity of grazing, but no long-term trends were discernible.

\section{Precipitation and Runoff}

Annual precipitation ranged from about 330 to $940 \mathrm{~mm}$ and averaged about $642 \mathrm{~mm}$ (Table 2), slightly higher than the longterm average of $617 \mathrm{~mm}$. As is the norm for this region, most of the precipitation occurred during the late spring and summer months (Fig. 2).

During the decade of observation, surface runoff made up a very small portion of the water budget-on average, less than $0.5 \%$ of the total rainfall (Table 2 ). Five of the microcatchments produced only trace amounts of runoff, even when rainfall was heavy. On average, the mesquite-dominated microcatchments produced more runoff than those dominated by redberry juniper, but this difference is of no practical importance.

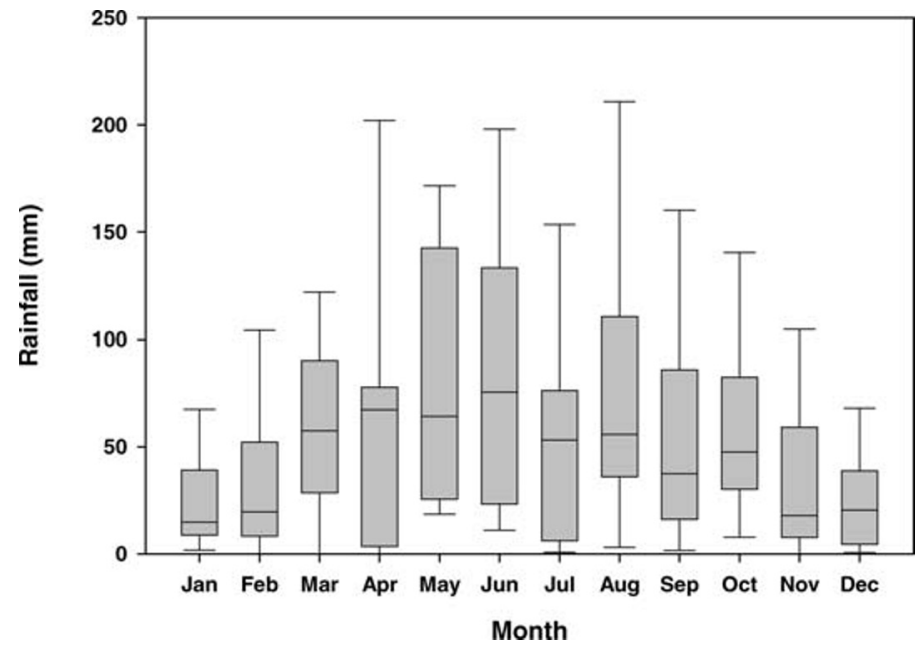

Figure 2. Box diagram showing the median, 10th, 25th, 75th, and 90th percentiles of monthly rainfall over the more than 9 years of the study.
In spite of the relatively small volume, runoff events were not uncommon. Between 17 and 30 runoff events were recorded for each of the microcatchments, and some 90 events were recorded for 1 microcatchment, MC8. However, it is probable that the presence of a cattle trail at the base of MC8 explains this exceptionally high number of runoff events. Most of the runoff was produced by a relatively small number of storms - the 5 largest accounting for about $75 \%$. Three of these storms occurred in the summer of 1995.

Clearly, in this region extraordinary weather conditions are required to generate surface runoff. For example, a storm that dropped about $220 \mathrm{~mm}$ of rain between 1 August 1995 and 4 August 1995 produced an average of only $8 \mathrm{~mm}$ of

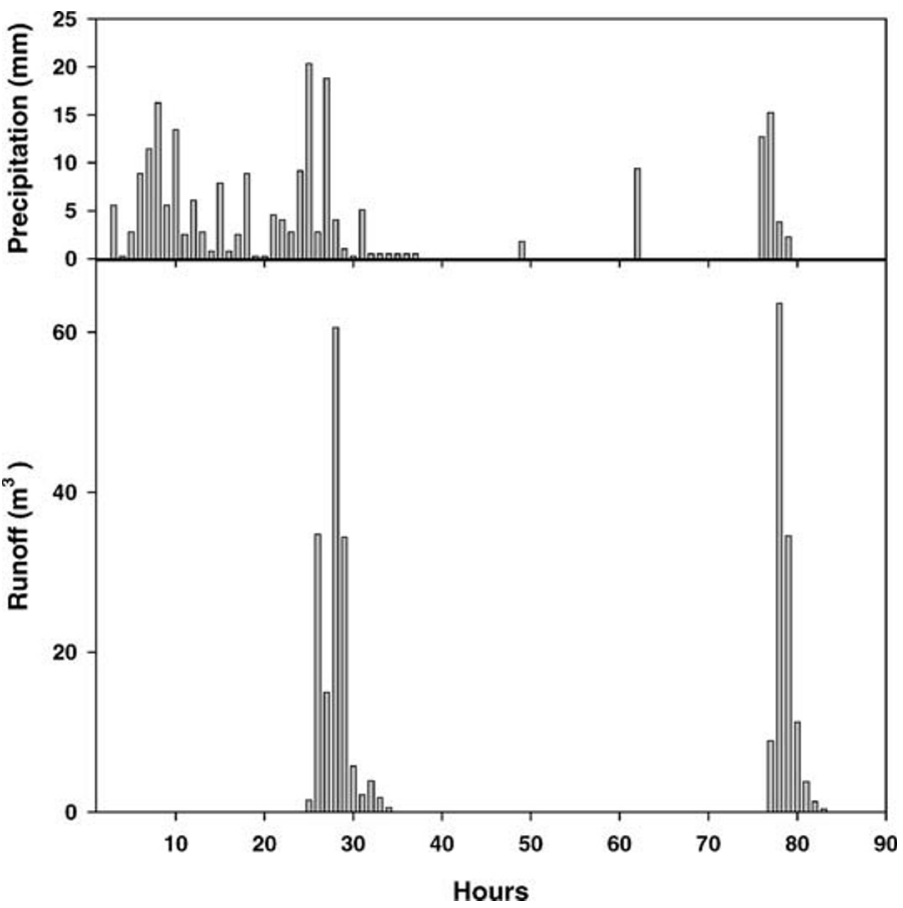

Figure 3. Rainfall and runoff from 1 August 1995 to 4 August 1995, for microcatchment 3 . 

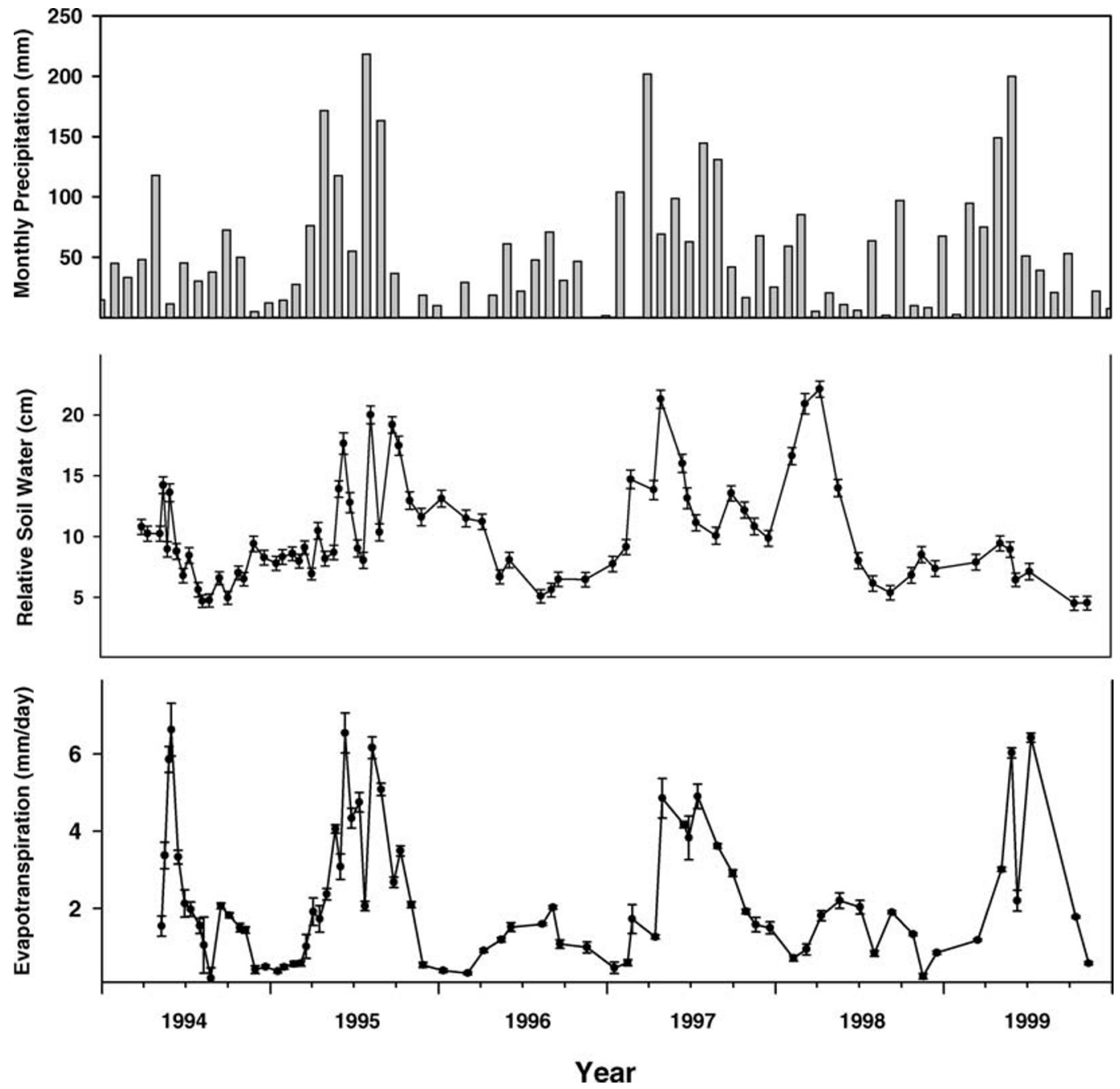

Figure 4. Monthly precipitation, relative soil water for the top $135 \mathrm{~cm}$ of soil, and estimated evapotranspiration rate from April 1994 to December 1999. Error bars indicate the standard error for each sampling date $(n=29)$.

runoff from each of the 9 microcatchments. But this average, interestingly, encompasses a wide range of differences: as much as $30 \mathrm{~mm}$ of runoff was generated by 1 microcatchment, MC3 (Fig. 3), whereas almost no runoff was produced from microcatchments $1,4,7,8$, or 9. For the other microcatchments, runoff did not begin until about $120 \mathrm{~mm}$ of rain had fallen. During the fourth and final day of the storm, average runoff efficiency (runoff as a \% of precipitation) was about $10 \%$-and as high as $37 \%$ from MC3. Runoff continued for 3 hours after rainfall had stopped.

\section{Soil Water Dynamics and Evapotranspiration}

A 6-year record of monthly precipitation, relative soil water, and evapotranspiration is presented in Figure 4. A more detailed breakdown of soil water with depth is provided in Figure 5. From 1994 to 2000, there were 3 major episodes of soil water recharge, as evidenced by increases in volumetric water in the deepest soil layers (Fig. 5). The 2 largest recharge events were the result of cool-season precipitation in 1997 and 1998. Summer rainfall was elevated in 1995, 1997, and 1999 (Fig. 4). However, these rains translated to deep soil water only in 1995. In that year, summer rainfall (May-September) amounted to $726 \mathrm{~mm}$-in contrast to $507 \mathrm{~mm}$ in 1997 and $460 \mathrm{~mm}$ in 1999. Clearly, for appreciable soil water recharge to occur during the summer months, rainfall must be exceptionally heavy. During the winter and early spring, however, relatively modest amounts of rainfall are sufficient to generate deep soil water storage-as occurred in 1997 and 1998.

The 6 years of soil moisture data from the $135-\mathrm{cm}$-depth samples were similar to measurements from a similarly textured soil profile in a nearby Texas Rolling Plains site studied by Carlson et al. (1990). They found that only $0.4 \%$ of the water percolated beyond a depth of $3 \mathrm{~m}$, thereby reinforcing the assumption that deep drainage losses on this type of site are negligible (it was on this basis that we used a deep drainage factor of 0 in our calculations).

As highlighted in Figure 4, ET was tightly coupled with summer rainfall. When summer rainfall was substantial, ET proceeded at a high rate for as long as the rains persisted. For example, in 1995, 1997, and 1999, high rates of ET continued through the entire growing season. In contrast, in 1996 and 1998, when summer rainfall was well below average, ET was 


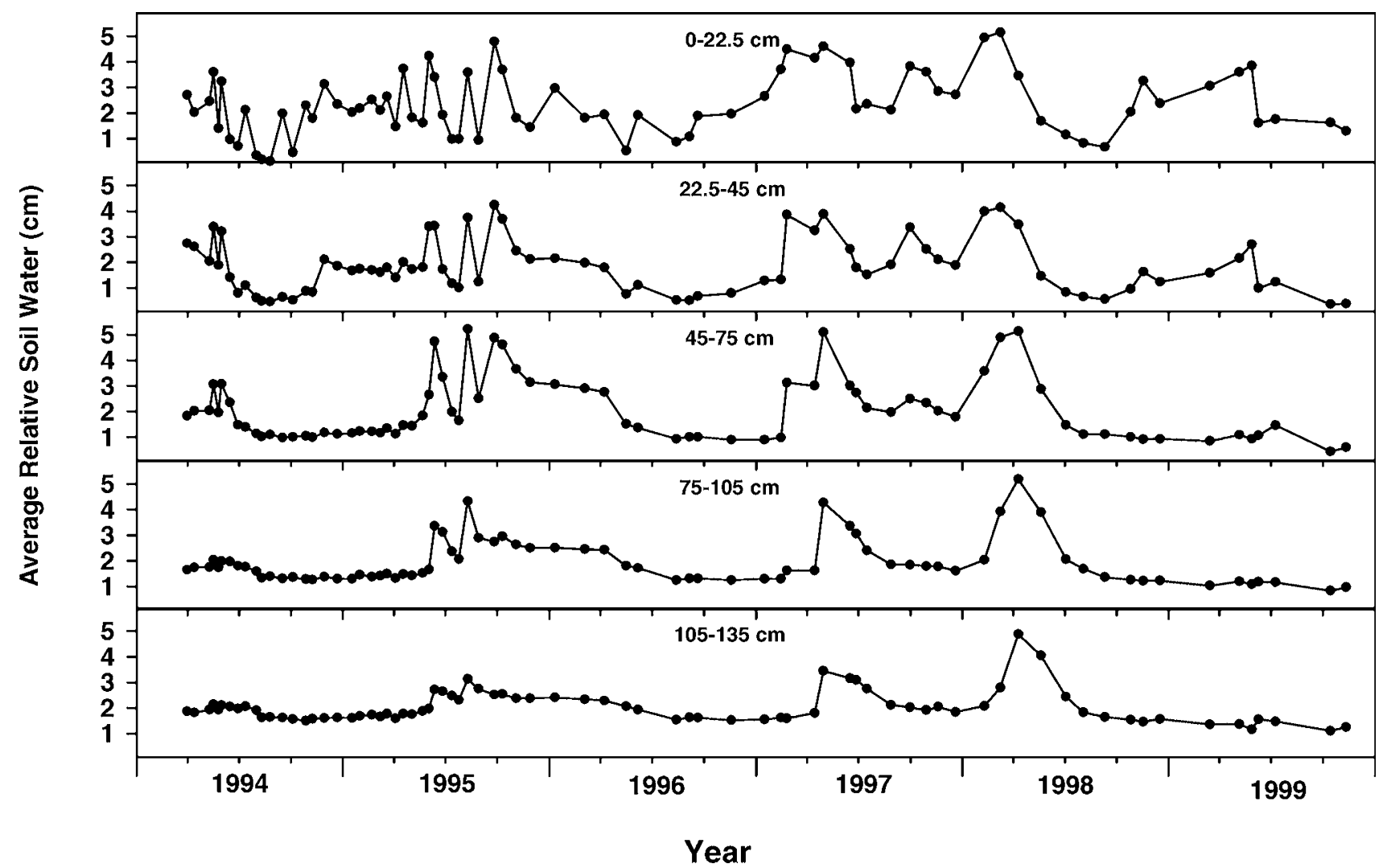

Figure 5. Relative soil water calculated for each sampling depth, April 1994 to December 1999. Error bars have been omitted to simplify the presentation.

greatly curtailed. As would be expected, during the winter ET was much diminished but never completely shut down.

\section{DISCUSSION AND MANAGEMENT IMPLICATIONS}

Water balance relationships in mesquite rangelands had previously been studied only at 3 sites: 1 in the Rolling Plains (Carlson et al. 1990), 1 in the South Texas Plains (Weltz and Blackburn 1995), and 1 in the Blackland Prairie (Richardson et al. 1979). In the Rolling Plains and South Texas Plains studies, runoff was measured from relatively small, nonweighing lysimeters ( 15 to $30 \mathrm{~m}^{2}$ ); such measurements, from smaller surface areas, tend to show a greater percentage of runoff than those from larger catchments (such as the 1.4-ha areas used in our study; Wilcox et al. 2006). The study in the Blackland Prairie was the only one in which runoff was measured from 2 catchments comparable in size (1.3 ha) to those of our study and for a period of time ( 7 years) similar to that of our study.

Although separated by more than $700 \mathrm{~km}$, the mesquitedominated Rolling Plains and South Texas Plains sites were similar in that little if any deep drainage occurred and surface runoff was generally less than $2 \%-3 \%$ of the water budget. In contrast, the Blackland Prairie site showed a quite different hydrologic character. The soils in this region are mainly Houston clays, which in periods of prolonged dryness develop surface cracks that then allow rapid and deep drainage when precipitation occurs. However, once these soils are wet, their infiltration capacity is very low; for this reason, surface runoff at this site averaged about $30 \%$ of the water budget.

Our study at the Y Experimental Ranch produced several interesting and important findings. The first is that for many shrublands in the Texas Rolling Plains, little surface runoff is ever generated-even by relatively large storm events. This finding contrasts markedly with a commonly held perception that surface runoff can be significant, particularly in the wake of large rains. For example, in describing rangelands in nearby Wilbarger County, Koos et al. (1962) state, "Extremely heavy rains of short duration may obscure situations of drought because, although they add to the total amount of rainfall recorded, most of the water runs off and does not penetrate the soil to any depth." Clearly this is not the case, at least where slopes are relatively gentle and soils deep. It may be that more runoff is generated on sites with steep slopes and shallow soils. Obviously, the dynamics of runoff in mesquite-dominated rangelands of the Rolling Plains are much different from those in mesquite rangelands of the clay-rich Blackland Prairie, where surface runoff approaches $30 \%$ of precipitation (Richardson et al. 1979).

Our estimates of daily ET in this study are comparable to those reported by Dugas and Mayeux (1991). For 2 summers, they used micrometeorological towers to monitor ET rates on mesquite rangelands in the Rolling Plains. Their findings showed that maximum daily ET was around $5 \mathrm{~mm} \cdot \mathrm{day}^{-1}$; and that during particularly dry periods, it dropped to almost 0 (it should be noted that both the summers of their study were 
characterized by below-average precipitation). The estimates from our study are average values, in most cases integrated over periods of 2 to 4 weeks.

Physiological investigations have demonstrated that transpiration rates for mesquite vary greatly, depending on the availability of water (Ansley et al. 1991, 1994, 1998). Ansley and coworkers concluded that mesquite in this region relies mostly on soil water supplied by rainfall rather than deeper groundwater. They found that mesquite can extract water from depths of over $120 \mathrm{~cm}$.

In summary, our study at the $\mathrm{Y}$ Experimental Ranch provides an important baseline for water balance relationships in mesquite and mesquite-juniper rangelands typical of the Texas Rolling Plains. In this region, practically all of the water input to the system as precipitation $(99 \%)$ exits via evapotranspiration. Very little water runs off or percolates deeper than the top $1 \mathrm{~m}$ of the soil. Large precipitation events $(>120$ $\mathrm{mm}$ storms) were responsible for almost all of this soil water as well as any runoff. On the basis of our results and other work on shrublands in the Rolling Plains, we believe there is little potential for increasing water supply (recharge and/or streamflow) by reducing shrub cover in landscapes of this type. We are increasingly confident in our assessment because of the longterm and relatively large-scale nature of this study.

\section{ACKNOWLEDGMENTS}

We are thankful for the expert field and laboratory assistance of Mr Andrew Weichert, Rangeland Ecology and Management Department, Texas A\&M University.

\section{LITERATURE CITED}

Ansley, R. J., W. A. Dugas, M. L. Heuer, and B. A. Trevino. 1994. Stem-flow and porometer measurements of transpiration from honey mesquite (Prosopis glandulosa). Journal of Experimental Botany 45:847-856.

Ansley, R. J., P. W. JacoBy, and R. A. Hicks. 1991. Leaf and whole plant transpiration in honey mesquite following severing of lateral roots. Journal of Range Management 44:577-583.

Ansley, R. J., W. E. Pinchak, And D. N. UeCKert. 1995. Changes in redberry juniper distributions in northwest Texas. Rangelands 17:49-53.

Ansley, R. J., B. A. Trevino, and P. W. Jacoby. 1998. Intraspecific competition in honey mesquite-leaf and whole plant responses. Journal of Range Management 51:345-352.

Ansley, R. J., X. B. Wu, and B. A. Kramp. 2001. Observation: long-term increases in mesquite canopy cover in a North Texas savanna. Journal of Range Management 54:171-176.

ARCHER, S. 1989. Have southern Texas savannas been converted to woodlands in recent history? American Naturalist 134:545-561.

ArcheR, S. 1996. Assessing and interpreting grass-woody plant dynamics. In: J. Hodgson and A. W. Illius [EDS.]. The ecology and management of grazing systems. Wallingford, UK: CAB International. p 101-134.

Archer, S., T. W. Boutton, and K. A. HibBard. 2001. Trees in grasslands: Biogeochemical consequences of woody plant expansion. In: E. Schultz et al. [EDS.]. Global biogeochemical cycles in the climate system. San Diego: Academic Press. p. 115-138.

Asner, G. P., S. Archer, R. F. Hughes, R. J. Ansley, and C. A. Wessman. 2003. Net changes in regional woody vegetation cover and carbon storage in Texas Drylands, 1937-1999. Global Change Biology 9:316-335.
Carlson, D. H., T. L. Thurow, R. W. Knight, and R. K. Heitschmidt. 1990. Effect of honey mesquite on the water balance of Texas Rolling Plains rangeland. Journal of Range Management 43:491-496.

Dowhower, S. L., W. R. Teague, R. J. Ansley, and W. E. Pinchak. 2001. Dry-weightrank method assessment in heterogeneous communities. Journal of Range Management 54:71-76.

Dugas, W. A., and H. S. Mayeux. 1991. Evaporation from rangeland with and without honey mesquite. Journal of Range Management 44:161-170.

Huxman, T. E., B. P. Wilcox, R. Scott, K. Snyder, D. D. Breshears, E. Small, K. Hultine, W. T. Pockman, and R. B. Jackson. 2005. Ecohydrological implications of woody plant encroachment. Ecology 86:308-319.

Koos, W. M., J. C. Williams, And M. L. Dixon. 1962. Soil survey-Wilbarger County, Texas. Washington DC: US Department of Agriculture, Soil Conservation Service. $64 \mathrm{p}$.

LaRKIN, T. J., AND G. W. Bomar. 1983. Climatic atlas of Texas. Texas Department of Water Resources. $151 \mathrm{p}$.

Loik, M. E., D. D. Breshears, W. K. Lauenroth, and J. Belnap. 2004. A multi-scale perspective of water pulses in dryland ecosystems: climatology and ecohydrology of the western USA. Oecologia 141:269-281.

Newman, B. D., B. P. Wilcox, S. Archer, D. D. Breshears, C. N. Dahm, C. J. Duffy, N. G. Mcdowell, F. M. Phillips, B. R. Scanlon, and E. R. Vivoni. 2006. Ecohydrology of water-limited environments: a scientific vision. Water Resources Research 42:W06302, doi: 10.1029/2005WR004141.

Ogle, K., and J. F. Reynolds. 2004. Plant responses to precipitation in desert ecosystems: integrating functional types, pulses, thresholds, and delays. Oecologia 141:282-294.

Reynolds, J. F., P. R. Kemp, K. Ogle, and R. J. Fernandez. 2004. Modifying the "pulse-reserve" paradigm for deserts of North America: precipitation pulses, soil water, and plant responses. Oecologia 141:194-210.

Richardson, C. W., E. Burnett, and R. W. Bovey. 1979. Hydrologic effects of brush control on Texas rangelands. Transactions of the ASAE 22:315-319.

Scanlon, B. R., R. C. Reedy, D. A. Stonestrom, and D. E. Prudic. 2005. Impact of land use and land cover change on groundwater recharge and quality in the Southwestern US. Global Change Biology 11:1577-1593.

Scholes, R. J., And S. R. Archer. 1997. Tree-grass interactions in savannas. Annual Review of Ecology and Systematics 28:517-544.

Schwinning, S., O. E. Sala, M. E. LoIK, and J. R. Ehleringer. 2004. Thresholds, memory, and seasonality: understanding pulse dynamics in arid/semi-arid ecosystems. Oecologia 141:191-193.

ScIFRES, C. J. 1980. Brush management: principles and practices for Texas and the Southwest. College Station, TX: Texas A\&M Press. $360 \mathrm{p}$.

Seyfried, M. S., S. Schwinning, M. A. Walvoord, W. T. Pockman, B. D. Newman, R. B. Jackson, and F. M. Phillips. 2005. Ecohydrological control of deep drainage in semiarid regions. Ecology 86:277-287.

Teague, W. R., S. L. Dowhower, S. G. Whisenant, and E. Flores-Ancira. 2001. Mesquite and grass interference with establishing redberry juniper seedlings. Journal of Range Management 54:680-684.

Thurow, A. P., J. R. Conner, T. L. Thurow, and M. D. Garriga. 2001. A preliminary analysis of Texas ranchers' willingness to participate in a brush control cost-sharing program to improve off-site water yields. Ecological Economics 37:139-152.

Weltz, M. A., and W. H. BlackbuRn. 1995. Water budget for south Texas rangelands. Journal of Range Management 48:45-52.

WILcox, B. P. 2002. Shrub control and streamflow on rangelands: a process-based viewpoint. Journal of Range Management 55:318-326.

Wilcox, B. P., K. W. Owens, W. A. Dugas, D. N. Ueckert, and C. A. Hart. 2006. Shrubs, streamflow, and the paradox of scale. Hydrological Processes 20:3277-3288.

Wilcox, B. P., M. S. Seyfried, and D. D. Breshears. 2003. The water balance on rangelands. In: B. A. Stewart and T. A. Howell [EDS.]. Encyclopedia of water science. New York: Marcel Dekker, Inc. p 791-794.

Wilcox, B. P., AND T. L. Thurow. 2006. Emerging Issues in rangleland ecohydrology: vegetation change and the water cycle. Rangeland Ecology and Management 59:220-224. 